\title{
Tumor microenvironment dictates regulatory $T$ cell phenotype: Upregulated immune checkpoints reinforce suppressive function
}

Hye Ryun Kim ${ }^{1 \dagger}$, Hyo Jin Park ${ }^{2 \dagger}$, Jimin Son ${ }^{2 \dagger}$, Jin Gu Lee ${ }^{3}$, Kyung Young Chung ${ }^{3}$, Nam Hoon Cho ${ }^{4}$, Hyo Sup Shim ${ }^{4}$, Seyeon Park ${ }^{2}$, Gamin Kim¹, Hong In Yoon ${ }^{5}$, Hyun Gyung Kim ${ }^{6}$, Yong Woo Jung ${ }^{6}$, Byoung Chul Cho', Seong Yong Park ${ }^{3^{*}}$, Sun Young Rha ${ }^{1^{*}}$ and Sang-Jun $\mathrm{Ha}^{2^{*}}$

\begin{abstract}
Background: Regulatory $T$ ( $T_{\text {reg }}$ ) cells have an immunosuppressive function in cancer, but the underlying mechanism of immunosuppression in the tumor microenvironment (TME) is unclear.

Methods: We compared the phenotypes of T cell subsets, including $T_{\text {reg }}$ cells, obtained from peripheral blood, malignant effusion, and tumors of 103 cancer patients. Our primary focus was on the expression of immune checkpoint (IC)-molecules, such as programmed death (PD)-1, T-cell immunoglobulin and mucin-domain containing (TIM)-3, T cell Ig and ITIM domain (TIGIT), and cytotoxic T lymphocyte antigen (CTLA)-4, on $T_{\text {reg }}$ cells in paired lymphocytes from blood, peritumoral tissue, and tumors of 12 patients with lung cancer. To identify the immunosuppressive mechanisms acting on tumor-infiltrating $T_{\text {reg }}$ cells, we conducted immunosuppressive functional assays in a mouse model.
\end{abstract}

Results: $\mathrm{CD}^{+}, \mathrm{CD}^{+} \mathrm{T}$ cells, and $\mathrm{T}_{\text {reg }}$ cells exhibited a gradual upregulation of IC-molecules the closer they were to the tumor. Interestingly, PD-1 expression was more prominent in $T_{\text {reg }}$ cells than in conventional $T\left(T_{\text {conv }}\right)$ cells. In lung cancer patients, higher levels of IC-molecules were expressed on $T_{\text {reg }}$ cells than on $T_{\text {conv }}$ cells, and $T_{\text {reg }}$ cells were also more enriched in the tumor than in the peri-tumor and blood. In a mouse lung cancer model, ICmolecules were also preferentially upregulated on $T_{\text {reg }}$ cells, compared to $T_{\text {conv }}$ cells. PD-1 showed the greatest increase on most cell types, especially $T_{\text {reg }}$ cells, and this increase occurred gradually over time after the cells entered the TME. PD-1 high-expressing tumor-infiltrating $T_{\text {reg }}$ cells displayed potent suppressive activity, which could be partially inhibited with a blocking anti-PD-1 antibody.

Conclusions: We demonstrate that the TME confers a suppressive function on $T_{\text {reg }}$ cells by upregulating ICmolecule expression. Targeting IC-molecules, including PD-1, on $\mathrm{T}_{\text {reg }}$ cells may be effective for cancer treatment.

Keywords: Tumor microenvironment, Regulatory T cells, Immune checkpoints, Programmed cell death 1 receptor

\footnotetext{
*Correspondence: syparkcs@yuhs.ac; rha7655@yuhs.ac; sjha@yonsei.ac.kr

†Hye Ryun Kim, Hyo Jin Park, Jimin Son contributed equally to this work and are joint first authors.

${ }^{3}$ Department of Thoracic and Cardiovascular Surgery, Yonsei University College of Medicine, 50 Yonsei-ro, Seodaemun-Gu, Seoul 120-752, South Korea

${ }^{1}$ Yonsei Cancer Center, Division of Medical Oncology, Yonsei University College of Medicine, 50 Yonsei-ro, Seodaemun-Gu, Seoul 120-752, South Korea

2Department of Biochemistry, College of Life Science \& Biotechnology,

Yonsei University, Seoul, South Korea

Full list of author information is available at the end of the article
}

C The Author(s). 2019 Open Access This article is distributed under the terms of the Creative Commons Attribution 4.0 International License (http://creativecommons.org/licenses/by/4.0/), which permits unrestricted use, distribution, and reproduction in any medium, provided you give appropriate credit to the original author(s) and the source, provide a link to the Creative Commons license, and indicate if changes were made. The Creative Commons Public Domain Dedication waiver (http://creativecommons.org/publicdomain/zero/1.0/) applies to the data made available in this article, unless otherwise stated. 


\section{Background}

The recent development of immune checkpoint inhibitors (ICIs) has revolutionized cancer treatment. ICIs specific for anti-cytotoxic T lymphocyte antigen (CTLA)-4 or anti-programmed death (PD)-1 have improved patient survival and have been approved for the treatment of several cancer types, including non-small cell lung cancer (NSCLC), melanoma, head and neck cancer, bladder cancer, and renal cell cancer [1-3].

The tumor microenvironment (TME) and the immune system play critical roles in cancer progression and clinical outcome $[4,5]$. Regulatory $\mathrm{T}\left(\mathrm{T}_{\text {reg }}\right)$ cells are highly immunosuppressive and contribute to the maintenance of self-tolerance and immune homeostasis in humans $[6$, 7]. $\mathrm{T}_{\text {reg }}$ cells infiltrate tumors and promote their progression by suppressing antitumor immunity in the TME. Depleting $\mathrm{T}_{\text {reg }}$ cells can lead to spontaneous tumor regression due to enhanced antitumor response $[7,8]$. Interaction of $\mathrm{T}_{\text {reg }}$ cells with TME enhances their immunosuppressive function and proliferative capacity. Several studies have shown that tumor-infiltrating $\mathrm{T}_{\text {reg }}$ cells are phenotypically distinct from those in peripheral blood $(\mathrm{PB})$ and normal tissues $[9,10]$, suggesting that their immunosuppressive function depends on environmental factors.

$\mathrm{T}_{\text {reg }}$ cells suppressive functions are associated with the expression of several immune checkpoint molecules (ICs), such as PD-1, CTLA-4, T-cell immunoglobulin and mucin-domain containing-3 (TIM)-3, and T cell Ig and ITIM domain (TIGIT) $[3,6,11-14]$. CTLA-4 and TIGIT act as tumor suppressors and thus, modulate the immune response in the TME $[6,15,16]$. Although the $\mathrm{PD}-1 / \mathrm{PD}$ ligand (PD-L)1 interaction was shown to promote the conversion of conventional $\mathrm{T}$ ( $\mathrm{T}_{\text {conv }}$ ) cells into $\mathrm{T}_{\text {reg }}$ cells to maintain the latter's population [17-19], it remains controversial whether PD-1 expression by $\mathrm{T}_{\text {reg }}$ cells suppresses antigen-specific $\mathrm{T}$ cell immune responses [20-22].

Recent studies have reported that IC-molecules are upregulated on $\mathrm{T}_{\text {reg }}$ cells within the TME or upon chronic infection and that $\mathrm{T}_{\text {reg }}$ cells-mediated immunosuppression correlates with the expression of ICmolecules on these cells $[6,12]$. The upregulation of these molecules has also been linked to tumor progression, as it likely reinforces the suppressive function of $\mathrm{T}_{\text {reg }}$ cells in the TME. We previously reported that an increased level of PD-1 on $\mathrm{T}_{\text {reg }}$ cells during chronic viral infection enhances $\mathrm{CD}^{+} \mathrm{T}$ cell immune suppression via interaction with PD-L1 on $\mathrm{CD}^{+} \mathrm{T}$ cells [12]. On the contrary, high PD-1 expression on $\mathrm{T}_{\text {reg }}$ cells indicates dysfunctional and exhausted IFN- $\gamma$-secreting $\mathrm{T}_{\text {reg }}$ cells that are enriched in tumor infiltrates and have possibly lost their suppressive function [23]. So far, the precise role of PD-1 in the function of tumor-infiltrating $\mathrm{T}_{\mathrm{reg}}$ cells in the TME is controversial. Given the significance of PD-1 in modulating immune responses and its paradoxical role as both an activation and exhaustion marker, clarifying the function of PD-1-positive $\mathrm{T}_{\text {reg }}$ cells and their role in regulating anti-tumor immune responses is important [23].

To evaluate the suppressive function of tumorinfiltrating $\mathrm{T}_{\text {reg }}$ cells in the TME, we comprehensively compared the phenotypes of $\mathrm{T}$ cell subsets, including $\mathrm{T}_{\text {reg }}$ cells, obtained from $\mathrm{PB}$, malignant effusion (ME), and tumor (TM) samples of patients with cancer. We also characterized $\mathrm{T}_{\text {reg }}$ cells in paired lymphocyte samples obtained from blood, peri-tumoral tissue, and tumors of patients with lung cancer. Using a lung cancer mouse model, we investigated the suppressive function and mechanism of action of tumor-infiltrating $\mathrm{T}_{\text {reg }}$ cells in the TME. We found that PD-1 was upregulated in tumor-infiltrating $\mathrm{T}_{\text {reg }}$ cells and played a role in suppressing $\mathrm{CD}^{+}{ }^{+} \mathrm{T}$ cell proliferation through $\mathrm{PD}-1 / \mathrm{PD}-\mathrm{L} 1$ interactions. These results suggest that infiltrated PD-1expressing $\mathrm{T}_{\text {reg }}$ cells in TME are a potential therapeutic target for anti-cancer treatment.

\section{Methods}

\section{Study design}

Patients with stage IV cancer with ME and patients with cancer who planned to undergo surgical resection between April 2012 and December 2017 at the Severance Hospital were prospectively enrolled. Inclusion criteria were as follows: 1 ) over 20 years old; 2 ) stage IV cancer with malignant pleural effusion or ascites confirmed by cytology, or cancer with scheduled surgery; and 3) written informed consent. We collected $300 \mathrm{cc}$ of effusions and simultaneously obtained $10 \mathrm{cc}$ of $\mathrm{PB}$ from patients with stage IV cancer with ME, if available. In patients who underwent surgery, we collected TM-adjacent normal tissue, and $10 \mathrm{cc}$ of $\mathrm{PB}$ to isolate peripheral blood lymphocytes (PBLs). The study was approved by the Institutional Review Board of Severance Hospital. We categorized the samples into three groups: 1) PBLs, 2) ME from patients with stage IV cancer, and 3) TM from patients with cancer who underwent surgery. To analyze the characteristics of $\mathrm{T}_{\text {reg }}$ cells in TME, we also collected paired peritumoral tissue lymphocytes (pTILs), tumorinfiltrating lymphocytes (TILs), and PBLs at the same day from 12 patients with NSCLC who underwent curative resection.

\section{Isolation of PB mononuclear cells and ME lymphocytes}

$\mathrm{PB}$ mononuclear cells were isolated from $10 \mathrm{cc}$ PB collected into EDTA tubes by separation over a Percoll (Sigma-Aldrich) gradient. Lymphocytes were isolated from $500 \mathrm{cc}$ of $\mathrm{ME}$ by discontinuous density gradient centrifugation on Percoll. To isolate TILs, lung TMs 
were chopped and then incubated with a solution containing $1 \mathrm{mg} / \mathrm{mL}$ collagenase type IV (Worthington Biochemical) and $0.01 \mathrm{mg} / \mathrm{mL}$ DNaseI (Sigma-Aldrich) at $37^{\circ} \mathrm{C}$ for $25 \mathrm{~min}$. TILs were isolated by Percoll gradient after washing dissociated tissues with ice-cold RPMI1640.

\section{Flow cytometry and antibodies}

Flow cytometry was performed using a FACS CANTOII (BD Biosciences, Franklin Lakes, NJ, USA) and CytoFLEX (Beckman Coulter, IN, USA). Data were analyzed using FlowJo software (Tree Star, OR, USA).

For immunolabeling of human samples, fluorophoreconjugated monoclonal antibodies against the following proteins were used: CD4 (RPA-T4), CD3 (OKT3), PD-1 (EH12.2H7), and CTLA-4 (BNI3) (all from Biolegend, San Diego, CA, USA); TIM-3 (344823) and TIGIT (741182) (both from R \& D Systems, Minneapolis, MN, USA); CD25 (M-A251) (BD Biosciences, Franklin Lakes, NJ, USA); and Foxp3 (PCH101) (eBioscience, San Diego, CA, USA). The LIVE/DEAD Fixable Red Dead Cell Stain kit was from Invitrogen (Carlsbad, CA, USA). $\mathrm{T}_{\text {reg }}$ cells labeled with various antibodies (except for the antibody against Foxp3) were fixed and permeabilized with Foxp3 fixation/ permeabilization solution (eBioscience). Foxp3 antibody was then administered for intracellular labeling of $T_{\text {reg }}$ cells. The proportion of $\mathrm{CD}^{+}$and $\mathrm{CD} 8^{+} \mathrm{T}$ cells among total lymphocytes was determined, and the fraction of Foxp3positive $\mathrm{CD} 4^{+} \mathrm{T}$ cells was quantified.

For immunolabeling of mouse samples, fluorophoreconjugated monoclonal antibodies against the following proteins were used: CD4 (RM4-5), Ly5.1 (A20), PD-1 (29F.1A12), TIM-3 (RMT3-23), NK1.1 (PK136), and DX5 (DX5) (all from Biolegend); and CD8 (53-6.7), CD25 (PC61.5), CTLA-4 (UC10-4B9), TIGIT (G1GD7), and F4/ 80 (BM8) (all from eBioscience); and CD11b (M1/79) (BD Biosciences). The LIVE/DEAD Fixable Near-IR Dead Cell Stain kit was from Invitrogen. $T_{\text {reg }}$ cells labeled with various antibodies (except for the antibodies against Foxp3 and CTLA-4) were fixed and permeabilized with Foxp3 fixation/permeabilization solution (eBioscience, San Diego, CA, USA). Foxp3 antibody was then administered for intracellular labeling of $\mathrm{T}_{\text {reg }}$ cells. The proportions of $\mathrm{CD} 4^{+}$and $\mathrm{CD}^{+} \mathrm{T}$ cells among lymphocytes were determined, and the fraction of Foxp3-positive $\mathrm{CD} 4^{+} \mathrm{T}$ cells was quantified. To prevent myeloid cells from non-specific staining, samples were preincubated with anti-CD16/32 (eBioscience) before immunolabeling with fluorophoreconjugated antibodies.

\section{Mouse TM model and lymphocyte isolation}

Female C57BL/6, C57BL/6-Rag2 ${ }^{-/-}$, and C57BL/6-Ly5.1 congenic mice (5-6 weeks) were purchased from Charles River Laboratories (Wilmington, MA, USA) and Jackson
Laboratories (Bar Harbor, ME, USA). To generate lung $\mathrm{TM}$ bearing mice, $5 \times 10^{5} \mathrm{TC}-1$ cells were intravenously injected into C57BL/6 mice via the tail-vein. Mice were sacrificed on day 21 post-injection. Lymphocytes were isolated from the spleen, normal lung, and lung tumor as previously described [9]. The number of tumor nodules on left upper lobe of the lung was counted at day 12,16 , and 21 post-injection. All animal protocols were approved by the Institutional Animal Care and Use Committee of the Yonsei University Laboratory Animal Research Center (2013-0115).

\section{In vitro suppression assay using mouse lymphocytes}

For the $\mathrm{T}_{\text {reg }}$ cells suppression assay, $\mathrm{CD} 4{ }^{+} \mathrm{CD} 25^{+} \mathrm{T}_{\text {reg }}$ cells $\left(10^{5} /\right.$ well $)$ were co-cultured with $\mathrm{CD}^{+} \mathrm{T}$ cells $\left(10^{5} /\right.$ well $)$ with Dynabeads mouse T-activator CD3/CD28 (Thermo Fisher Scientific, Waltham, MA, USA) in a 96-well Ubottom plate at $37^{\circ} \mathrm{C}$ for $72 \mathrm{~h}$. For the CellTrace Violet dilution assay, $\mathrm{CD}^{+} \mathrm{T}$ cells were isolated from the spleen of naïve mice using a $\mathrm{CD} 8^{+} \mathrm{T}$ Cell Isolation kit (Miltenyi Biotec, Bergisch Gladbach, Germany) and labeled with $5 \mu \mathrm{M}$ CellTrace Violet (Thermo Fisher Scientific). $\mathrm{CD}^{+} \mathrm{CD} 25^{+}$ $\mathrm{T}_{\text {reg }}$ cells were separately isolated from the spleen and tumor of TM-bearing mice on day 21 post-injection using $\mathrm{CD} 4{ }^{+} \mathrm{CD} 25^{+}$Regulatory T Cell Isolation kit (Miltenyi Biotec, Bergisch Gladbach, Germany). To inhibit cell migration, Transwell membranes $(0.4 \mathrm{~mm}$ pore; BD Biosciences) were inserted into 24 -well plate. $\mathrm{CD} 44^{+} \mathrm{CD} 25^{+} \mathrm{T}_{\text {reg }}$ cells $\left(10^{6} /\right.$ well) were co-cultured with $\mathrm{CD} 8^{+} \mathrm{T}$ cells $\left(10^{6} /\right.$ well $)$ with Dynabeads mouse T-activator CD3/CD28 (Thermo Fisher Scientific) in a 24 -well plate at $37^{\circ} \mathrm{C}$ for $72 \mathrm{~h}$.

For PD-1 blockade in tumor-infiltrating $\mathrm{T}_{\text {reg, }}$ $\mathrm{CD}^{+}{ }^{+} \mathrm{CD} 25^{+} \mathrm{T}_{\text {reg }}$ cells $\left(2.5 \times 10^{4} /\right.$ well $)$ isolated from tumor lymphocytes of TM bearing mice on day 14 postinjection were preincubated with $10 \mu \mathrm{g} / \mathrm{mL}$ anti-PD-1 antibody (RMP1-14) or rat IgG2a isotype control (2A3) (Bio X Cell) at $4{ }^{\circ} \mathrm{C}$ for $1 \mathrm{~h}$, washed twice, and then cocultured with $\mathrm{CD} 8^{+} \mathrm{T}$ cells $\left(10^{5} /\right.$ well $)$ in the presence of mouse T-activator CD3/CD28 Dynabeads for $68 \mathrm{~h}$.

\section{Adoptive cell transfer for in vivo suppression assay}

To examine the functionality of TIL $\mathrm{T}_{\text {reg }}\left(\mathrm{PD}-1^{\text {hi }}\right)$ and spleen $\mathrm{T}_{\text {reg }}\left(\mathrm{PD}-1^{\text {lo }}\right)$ cells, $\mathrm{CD} 4^{+} \mathrm{CD} 25^{+} \mathrm{T}_{\text {reg }}$ cells were isolated from the tumor and spleen of TM bearing mice at day 21 post-injection using $\mathrm{CD} 4^{+} \mathrm{CD} 25^{+}$Regulatory T Cell Isolation kit (Miltenyi Biotec). Ly5.1 $1^{+} \mathrm{CD}^{+} \mathrm{T}$ cells were isolated from naïve C57BL/6-Ly5.1 congenic mice. Ly5.1 $1^{+}$ $\mathrm{CD}^{+} \mathrm{T}$ cells $\left(2 \times 10^{6}\right)$ were injected i.v. into recipient Rag2 ${ }^{-/-}$mice alone or with Ly5.2 $2^{+}$TIL $\mathrm{T}_{\text {reg }}$ or spleen $\mathrm{T}_{\text {reg }}$ $\left(1 \times 10^{6}\right)$. At day 7 after cell transfer, splenocytes isolated from Rag2 $2^{-/-}$mice were analyzed for homeostatic expansion of the Ly5.1 $1^{+} \mathrm{CD}^{+} \mathrm{T}$ cell population using FACS. 
In vitro suppression assay using human lymphocytes $\mathrm{CD} 4{ }^{+} \mathrm{CD} 25^{+} \mathrm{T}_{\text {reg }}$ cells were isolated from the tumor tissue and peripheral blood of NSCLC patients, using human $\mathrm{CD} 4{ }^{+} \mathrm{CD} 25^{+} \mathrm{CD} 127^{\mathrm{dim} /-}$ Regulatory $\mathrm{T}$ Cells Isolation Kit II (Miltenyi Biotec, Bergisch Gladbach, Germany). $\mathrm{CD}^{+} \mathrm{T}$ cells were isolated from the paired peripheral blood of NSCLC patients using human $\mathrm{CD}^{+}$ T Cell Isolation kit (Miltenyi Biotec, Bergisch Gladbach, Germany) and subsequently labeled with $5 \mu \mathrm{M}$ CellTrace Violet. The $\mathrm{CD}^{+} \mathrm{T}$ cells $\left(10^{5} /\right.$ well $)$ were co-cultured with $\mathrm{CD} 4{ }^{+} \mathrm{CD} 25^{+} \mathrm{T}_{\text {reg }}$ cells $\left(5 \times 10^{4} /\right.$ well $)$ isolated from either tumor tissue or peripheral blood in the presence of $2.5 \mu \mathrm{l} /$ well of Dynabeads human T-activator CD3/28 (Thermo Fisher Scientific) at $37^{\circ} \mathrm{C}$ for $72 \mathrm{~h}$.

\section{Multi-color immunofluorescence analysis}

For multicolor immunofluorescence analysis, lungs were isolated, fixed with $2 \%$ paraformaldehyde/phosphate buffered saline overnight at $4{ }^{\circ} \mathrm{C}$, and then embedded in OCT compound (Sakura). Tissue blocks were frozen in 2-methyl butane and cooled on dry ice. Frozen blocks were cut to a thickness of $8 \mu \mathrm{m}$ and mounted on the silane-coated slide. Sections were stained with 4,6-diamidino-2-phenylindole (DAPI; Invitrogen) and with antibodies for anti-CD8 $\alpha$ (Clone 53-6.7), anti-CD4 (clone RM4-5), anti-CD279 (clone RMP1-30), and anti-GFP (clone 1GFP63) for amplification of Foxp3-GFP signals (Biolegend). Streptavidinconjugated horseradish peroxidase was used for staining of biotin-conjugated antibodies, and TSA Cyanine 3 Tyramidetetramethylrhodamine reagent (SAT704A001EA; PerkinElmer) was subsequently added for amplification. Images was acquired using a microscope (Carl Zeiss Co. Ltd) and analyzed with Image $1.50 \mathrm{~b}$ software.

\section{Statistical analysis}

Data were analyzed using Prism 5.0 software (GraphPad Inc., CA, USA). The Student's $t$-test, one-way analysis of variance, and the least significant difference test were used, where appropriate, to evaluate the significance of differences among groups. All statistical analyses were conducted with a significance level of $\alpha=0.05(P<0.05)$.

\section{Results}

\section{Patient characteristics}

We enrolled 103 patients: 72 were stage IV cancer patients with ME, and 31 were patients with operable disease (not stage IV) who underwent surgical resection. Detailed information of the patients from which PB, ME, or TM were obtained is described in Additional file 6: Table S1. The total number of tumor specimens was divided into three groups based on the specimen type: $\mathrm{PB}$, 20.7\% (28/135); ME, 56.2\% (76/135); and TM, $23.1 \%$ (31/135). Detailed analyses of immune subsets as well as the levels of their immune checkpoints were performed in PBLs (PB group), effusion-infiltrating lymphocytes (EILs) (ME group), and TILs (TM group). Primary cancer types in the ME group were NSCLC, 43.1\% (31/72); gastric cancer, $22.2 \%$ (16/72); colon cancer, 5.6\% (4/72), and breast cancer, $5.6 \%(4 / 72)$. The types of ME were ascites, 59.7\% (43/76) and pleural effusion, 45.8\% (33/76), with four patients having both (Additional file 6: Table S1). The presence of malignant cancer cells and TILs in TM or ME was pathologically or cytologically confirmed (Fig. 1a).

\section{$\mathrm{T}_{\text {conv }}$ with exhausted phenotypes are abundant in TM and ME}

To investigate $\mathrm{T}$ cell subsets in three different tumor specimens, we compared the ratio of $\mathrm{CD} 4^{+}$and $\mathrm{CD} 8^{+} \mathrm{T}$ cells in PBLs, EILs, and TILs isolated from PB, ME, and $\mathrm{TM}$, respectively. The percentage of $\mathrm{CD}^{+} \mathrm{T}$ cells was higher among TILs than among PBLs or EILs. In contrast, the percentage of $\mathrm{CD}^{+} \mathrm{T}$ cells was markedly lower among TILs than among PBLs or EILs (Fig. 1b), suggesting that the migration of cytotoxic lymphocytes (CTLs) into the TM was inhibited.

The phenotypes of PBLs, EILs, and TILs were compared by quantifying $\mathrm{CD} 4^{+}$and $\mathrm{CD} 8^{+} \mathrm{T}$ cells expressing PD-1 and TIM-3. The percentage of PD-1- or TIM-3expressing $\mathrm{CD}^{+}$or $\mathrm{CD}^{+} \mathrm{T}$ cells was the highest among TILs, with lower percentages in EILs and PBLs (Fig. 1c, $\mathrm{d}$ ), suggesting that $\mathrm{T}$ cells derived from $\mathrm{TM}$ and $\mathrm{ME}$ show more pronounced $\mathrm{T}$ cell exhaustion than those derived from PBLs.

\section{High expression of PD-1 in $\mathrm{T}_{\text {reg }}$ cells of ME and TM}

We next examined how $\mathrm{T}_{\text {reg }}$ cells expressing forkhead box (Fox) p3 are distributed and differ phenotypically in $\mathrm{PB}, \mathrm{ME}$, and TMs. $\mathrm{T}_{\text {reg }}$ cells showed greater accumulation in TILs than in PBLs and EILs of patients or in PBLs of healthy controls (Fig. 2a). Interestingly, $T_{\text {reg }}$ cells in TILs expressed a higher level of PD-1 than those in PBLs and EILs; moreover, the PD-1-expressing Foxp3 $3^{+}$ population among $\mathrm{CD} 4^{+} \mathrm{T}$ cells was also larger in TILs than in EILs, which, in turn, had a larger population than PBLs (Fig. 2b). To further characterize $\mathrm{CD}^{+} \mathrm{T}$ cells in different tissues, we compared PD-1 in Foxp $3^{+}$ and Foxp $3^{-} \mathrm{CD}_{4}^{+} \mathrm{T}$ cells (Fig. 2c). The proportion of PD-1-expressing cells in both $\mathrm{CD} 4^{+}$cells was larger in EILs and TILs than in PBLs. These results indicate that PD-1 expression by $T_{\text {reg }}$ cells and $T_{\text {conv }}$ cells clearly reflect the TME, as PD-1 expression increased in the following order: TILs > EILs > PBLs.

We next investigated whether the characteristics of $\mathrm{CD}^{+} \mathrm{T}$ cells, $\mathrm{CD}^{+} \mathrm{T}$ cells, and $\mathrm{T}_{\text {reg }}$ cells were altered in MEs depending on the cancer type. As shown in Additional file 1: Figure S1, the abundance of these cells and their expression of PD-1 in MEs were comparable in 


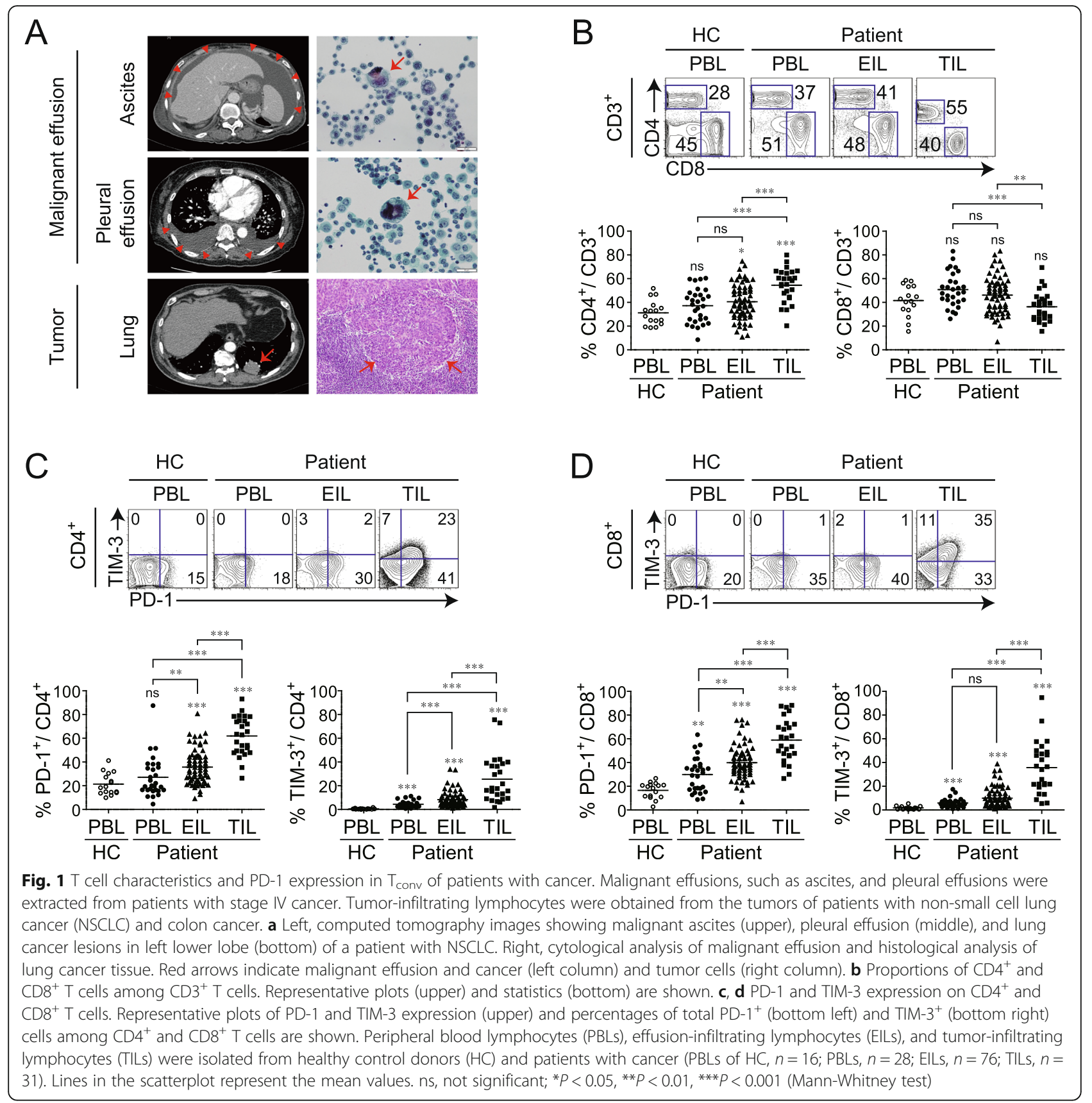

different types of cancer, although it is worth noting that there were more $\mathrm{T}_{\text {reg }}$ cells than there were $\mathrm{CD} 4^{+}$or $\mathrm{CD}^{+} \mathrm{T}_{\text {conv }}$ cells expressing PD- 1 . Interestingly, the degree of infiltration of PD- $1^{+} \mathrm{T}_{\text {reg }}$ cells did not differ among ME samples derived from the different types of cancer, indicating that the presence of PD- $1^{+} \mathrm{T}_{\text {reg }}$ cells in ME is a common feature across cancers of distinct histological origin (Additional file 1: Figure S1). Additionally, we compared the phenotype of $\mathrm{T}_{\text {reg }}$ between ascites and pleural effusion. As shown in Additional file 2: Figure S2, significant differences of the percentages of Foxp $3^{+} \mathrm{T}_{\text {reg }}$ and PD- ${ }^{+}$Foxp $^{+} \mathrm{T}_{\text {reg }}$ cells were not observed between ascites and pleural effusion. Moreover, the ascites and pleural effusions had a similar expression rate of PD-1 in Foxp $3^{+} \mathrm{T}_{\text {reg }}$ and Foxp3 $3^{-} \mathrm{T}_{\text {conv }}$ cells.

Tumor-infiltrating $T_{\text {reg }}$ are abundant in patients with lung cancer and express multiple IC-molecules

To clarify the characteristics of $\mathrm{T}_{\text {reg }}$ cells in the TME, we compared the frequency of $\mathrm{T}_{\text {reg }}$ cells and the expression of IC-molecules such as PD-1, TIM-3, TIGIT, and CTLA-4 in paired sets of tissue-derived lymphocytes, such as PBLs, pTILs, and TILs collected from 12 patients with NSCLC. As expected, $\mathrm{T}_{\text {reg }}$ cells were 

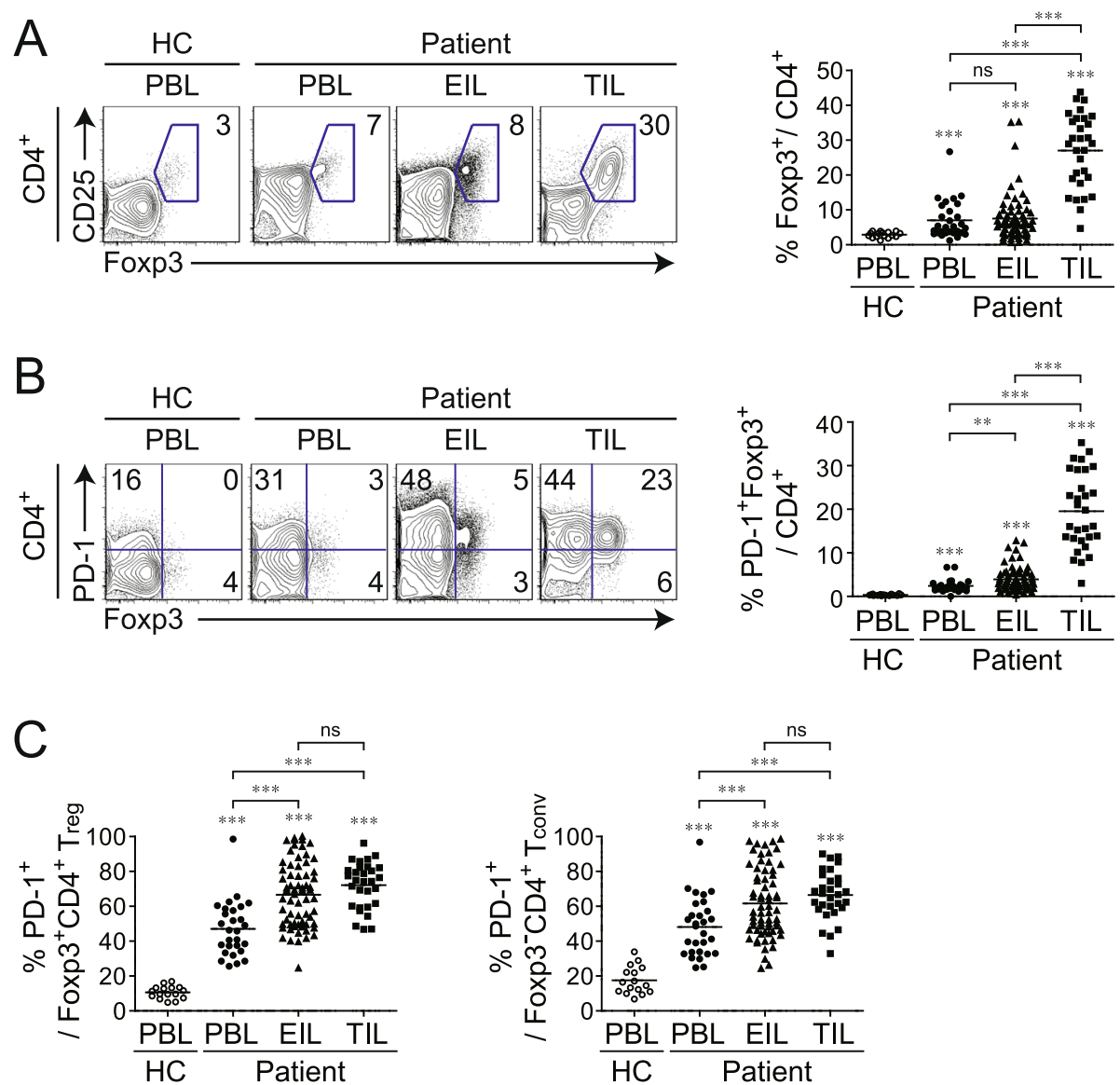

Fig. 2 PD-1 expression in Foxp3 ${ }^{+} T_{\text {reg }}$ in different tissue types of patients with cancer. a Representative plots of CD25 and Foxp3 expression (left) and proportion of Foxp3 ${ }^{+} \mathrm{T}$ cells (right) among CD4 ${ }^{+} \mathrm{T}$ cells. $\mathbf{b}$ Representative plots of PD-1 and Foxp3 expression (left) and proportion of PD-1 and Foxp3 co-expressing cells among total CD4 ${ }^{+} \mathrm{T}$ cells (right). c Summary of PD-1-positive fraction of Foxp3 ${ }^{+} \mathrm{T}_{\text {conv }}$ (left) and Foxp3 ${ }^{-} \mathrm{T}_{\text {reg }}$ (right) cell populations among CD4 ${ }^{+} \mathrm{T}$ cells. Peripheral blood lymphocytes (PBLs), effusion-infiltrating lymphocytes (EILs), and tumor-infiltrating lymphocytes (TILs) were isolated from healthy control donors (PBL, $n=16$ ) and patients with cancer (PBL, $n=28 ; E I L, n=76 ; T I L, n=31$ ). Lines in the scatterplot represent the mean values. ns, not significant; ${ }^{* *} P<0.01,{ }^{* * *} P<0.001$ (Mann-Whitney test)

more highly enriched in TILs than in pTILs and PBLs (Fig. 3a). Moreover, more $\mathrm{T}_{\text {reg-expressing } \mathrm{ICs}}$ were found among TILs than among pTILs and PBLs (Fig. 3b).

We also compared IC-molecule expression on different tumor-infiltrating $\mathrm{T}$ cell subsets. Among four different IC-molecules, PD-1 most clearly distinguished TME in all $\mathrm{T}$ cell subsets, because a significant increase in the $\mathrm{PD}-1^{+}$population was observed in the following order TIL > pTIL > PBL (Fig. 3c). Notably, PD-1 was higher in tumor-infiltrating Foxp $^{+} \mathrm{T}_{\text {reg }}$ cells $(\sim 98 \%)$ than in Foxp $3^{-} \mathrm{T}_{\text {conv }}$ cells $(\sim 82 \%)$ or $\mathrm{CD}^{+} \mathrm{T}_{\text {conv }}$ cells $(78 \%)$. Furthermore, the number of PD-1-expressing tumorinfiltrating Foxp $3^{+} \mathrm{T}_{\text {reg }}$ cells was greater than the number of tumor-infiltrating Foxp $3^{+} \mathrm{T}_{\text {reg }}$ cells expressing other IC-molecules. It is therefore conceivable that PD-1 expression on $\mathrm{T}_{\text {reg }}$ cells is a TME marker. Additionally, we performed the in vitro suppressive assay using isolated $\mathrm{CD} 4{ }^{+} \mathrm{CD} 25^{+} \mathrm{T}_{\text {reg }}$ cells from the peripheral blood and tumor tissue of NSCLC patients and isolated CD8 ${ }^{+}$ $\mathrm{T}$ cells from the peripheral blood. Each tumorinfiltrating $\mathrm{T}_{\text {reg }}$ cells or peripheral $\mathrm{T}_{\text {reg }}$ cells was cocultured with peripheral CD $8^{+} \mathrm{T}$ cells with $\alpha \mathrm{CD} 3 / \mathrm{CD} 28$ stimulation. $\mathrm{CD}^{+} \mathrm{T}$ cells proliferated at a high rate in the absence of $\mathrm{T}_{\text {reg }}$ cells and were more potently inhibited by $\mathrm{PD}-\mathrm{1}^{\text {hi }}$ tumor-infiltrating $\mathrm{T}_{\text {reg }}$ cells than by $\mathrm{PD}$ $1^{\text {lo }}$ PBMC $\mathrm{T}_{\text {reg }}$ cells (Fig. 3d).

\section{$\mathrm{T}_{\text {reg }}$ numbers and the expression of IC-molecules are} altered during cancer progression in a mouse model We previously showed that immune-exhaustion markers were highly expressed in tumor-infiltrating $\mathrm{T}_{\text {reg }}$ cells of patients with NSCLC. We therefore investigated the $\mathrm{T}_{\text {reg }}$ phenotype in greater detail in different tissues, using a mouse lung cancer model. We compared the expression levels of IC-molecules, such as PD-1, TIM-3, and TIGIT, on $\mathrm{CD}^{+}$and $\mathrm{CD}^{+} \mathrm{T}$ cells in different tissues from naïve and TM-bearing mice. As in patients with cancer 

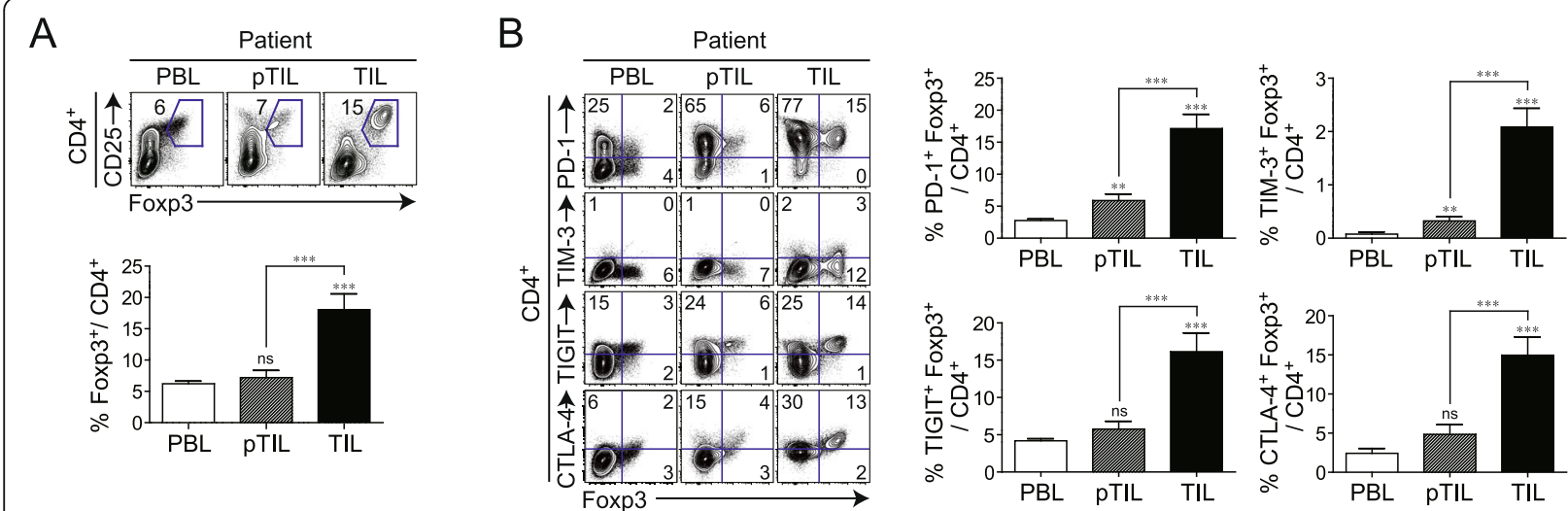

C
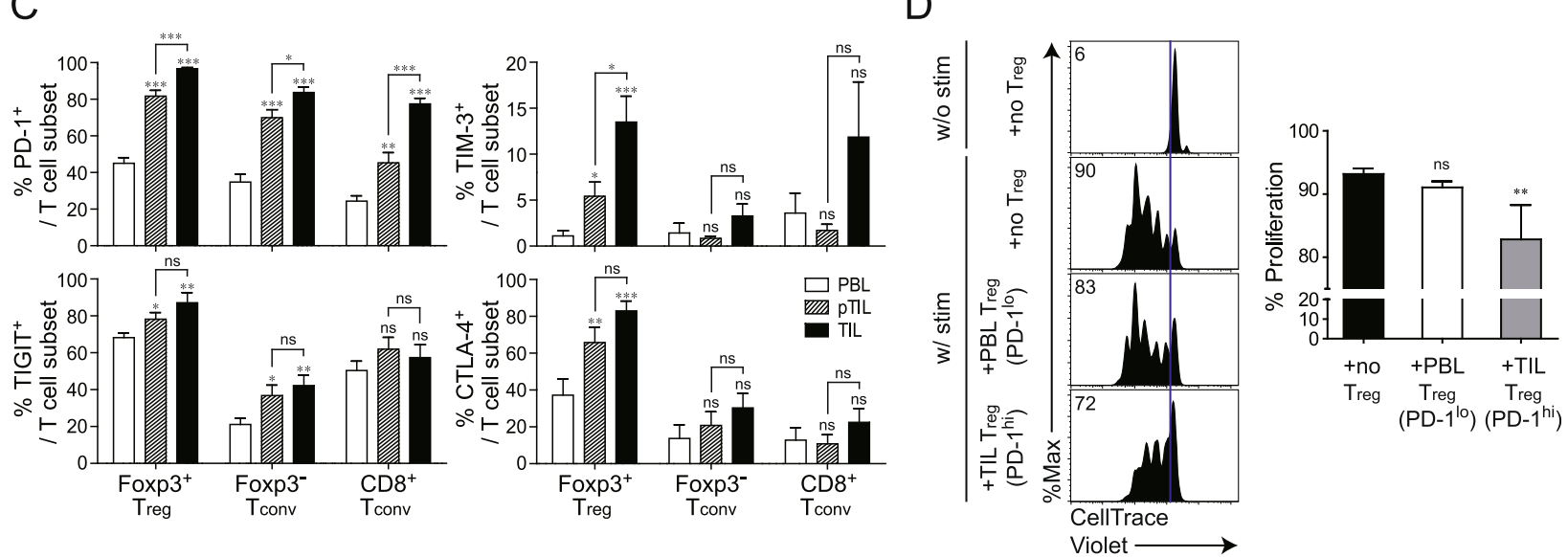

Fig. 3 PD-1-expressing tumor-infiltrating $T_{\text {reg }}$ and their activated phenotype in patients with non-small cell lung cancer (NSCLC). a CD25 and Foxp3 expression in $\mathrm{CD}^{+} \mathrm{T}$ cells (upper) and proportion of Foxp3 ${ }^{+}$cells among total CD4 ${ }^{+} \mathrm{T}$ cells (lower) in peripheral blood lymphocytes (PBLs), peritumoral infiltrating lymphocytes (pTILs), and tumor-infiltrating lymphocytes (TILs) derived from patients with NSCLC. $\mathbf{b}$ Representative plots of PD-1, TIM-3, TIGIT, CTLA-4, and Foxp3 expression in CD4 ${ }^{+} \mathrm{T}$ cells (left) and percentage of CD4 ${ }^{+} \mathrm{T}$ cells co-expressing PD-1, TIM-3, TIGIT, CTLA-4, and Foxp3 (right). c PD-1, TIM-3, TIGIT, and CTLA-4 expression in Foxp3 ${ }^{+} T_{\text {reg, }}$ Foxp3 ${ }^{-} T_{\text {conv }}$ and $C D 8^{+} T_{\text {conv }}$ of these patients. $\mathbf{d}$ Enhanced suppression of $\mathrm{CD}^{+} \mathrm{T}$ cells by PD-1-expressing tumor-infiltrating $\mathrm{T}_{\text {reg }}$ from NSCLC patients. $T_{\text {reg }}$ were isolated from the peripheral blood and tumor tissue from NSCLC patients. Peripheral blood $T_{\text {reg }}$ and tumor-infiltrating $T_{\text {reg }}$ expressed low and high levels of PD-1, respectively. CellTrace Violet (CTV)-labeled CD8 ${ }^{+} \mathrm{T}$ cells were stimulated in vitro with CD3/CD28 Dynabeads for $96 \mathrm{~h}$ in the absence or presence of each $\mathrm{T}_{\text {reg }}$ population. CTV dilution in proliferating $C D 8^{+} \mathrm{T}$ cells is indicated in each histogram. Histograms represent the percentages of proliferating cells. Lines in the bar graph represent the mean and mean \pm SEM, respectively. $n s$, not significant; ${ }^{* *} P<0.01,{ }^{* * *} P<0.001$ (Mann-Whitney test)

tissue, the expression of $\mathrm{IC}$-molecules in $\mathrm{CD}^{+}$and $\mathrm{CD}^{+} \mathrm{T}$ cells was much higher in lung $\mathrm{TM}$ than in $\mathrm{PB}$ or spleen (Fig. 4a, b). Among the populations expressing IC-molecules, PD-1-expressing $\mathrm{CD} 4^{+}$and $\mathrm{CD} 8^{+} \mathrm{T}$ cells were more abundant in the TM.

We next examined whether IC-molecules are preferentially upregulated on $\mathrm{T}_{\text {reg }}$ cells (compared to $\mathrm{T}_{\text {conv }}$ ) in $\mathrm{TM}$, as was observed in patient tissues. $\mathrm{PB}$, spleen, and lung lymphocytes were isolated at different time points after TC-1 injection (Fig. 5a). Starting at 12 days after $\mathrm{TC}-1$ injection, an increase in the number of Foxp $3^{+} \mathrm{T}_{\text {reg }}$ cells was observed in $\mathrm{TM}$ and the $\mathrm{T}_{\text {reg }}$ cells fraction reached $20 \%$ of total $\mathrm{CD} 4^{+} \mathrm{T}$ cells, a nearly 3 -fold increase compared to that in the non-TM lung (Fig. 5b). At 3 weeks after TC-1 injection, Foxp $3^{+} \mathrm{T}_{\text {reg }}$ cells were more abundant in the
TM than in the PB or spleen (Fig. 5c). Foxp3 ${ }^{+} \mathrm{T}_{\text {reg }}$ cells in TM showed significant increases in PD-1, TIM-3, TIGIT, and CTLA-4, compared to other tissues (Fig. $5 \mathrm{~d}$ ). Moreover, tumor-infiltrating $\mathrm{T}_{\text {reg }}$ cells expressed much higher levels of IC-molecules than tumor-infiltrating $\mathrm{T}_{\text {conv }}$ (Fig. 5e). Most $\mathrm{T}_{\text {reg }}$ cells $(\sim$ $80 \%)$, but only a low frequency of $\mathrm{T}_{\text {conv }}(\sim 20 \%)$ expressed PD-1 in TM. PD-1 was markedly upregulated 21 days after TC- 1 injection, and the same trend was observed for TIM-3 and TIGIT, although the increases in the levels of these molecules were less prominent (Fig. 5f). Unlike PD-1, TIM-3, and TIGIT, CTLA-4 was already upregulated in $\mathrm{T}_{\text {reg }}$ cells before TC-1 injection and its expression progressively increased over time (Fig. 5f). Thus, expression of ICmolecules, especially PD-1, on $\mathrm{T}_{\text {reg }}$ cells increases 

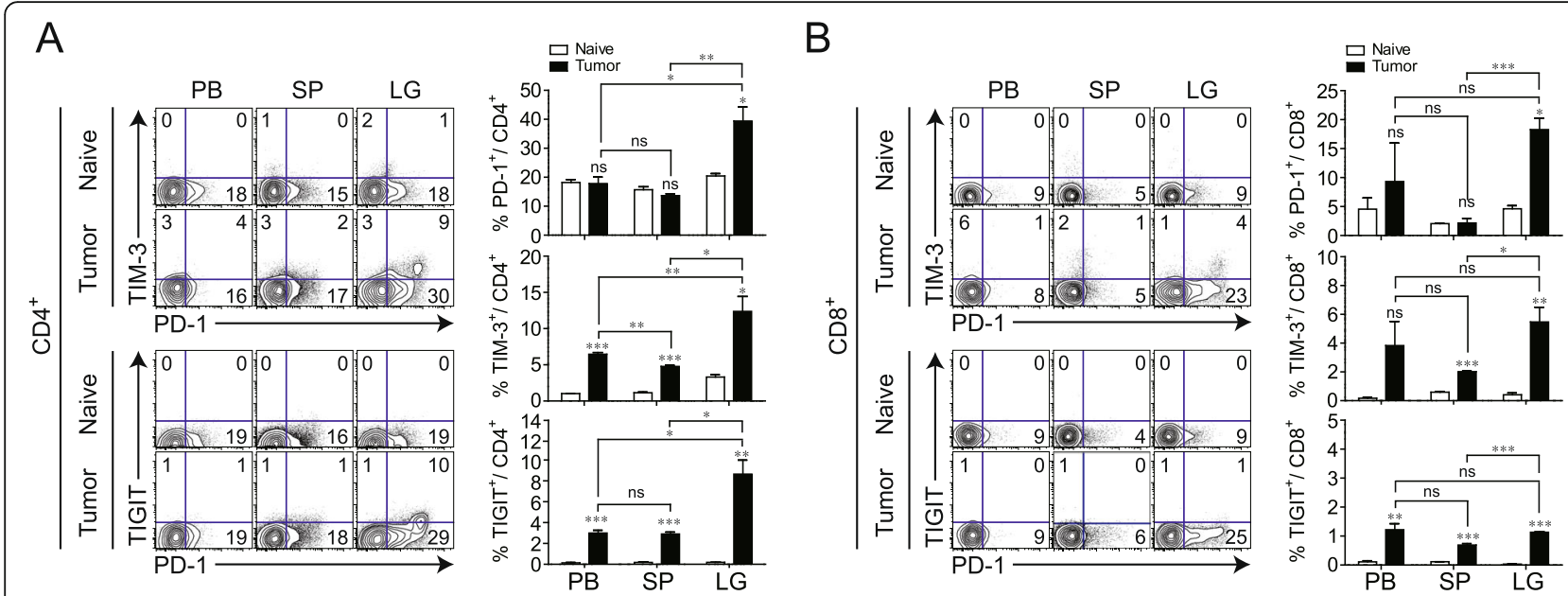

Fig. 4 Differential expression of immune checkpoint (IC) molecules on $C D 4^{+}$and $C D 8^{+} T$ cells in mice with lung cancer. To induce lung adenocarcinoma, TC-1 cells were intravenously injected into syngeneic mice. $\mathbf{a}$, $\mathbf{b}$ Tumor-bearing mice at 3 weeks after TC-1 cell injection and naïve control mice were sacrificed, and lymphocytes were isolated from peripheral blood (PB), spleen (SP), and lung (LG). (Left) Expression levels of PD-1, TIM-3, and TIGIT on CD4 ${ }^{+}$and $C D 8^{+} T$ cells were assessed. (Right) Summary of the proportions of IC molecules expressed on populations of $\mathrm{CD}^{+}$and $C D 8^{+} T$ cells in $\mathrm{PB}, \mathrm{SP}$, and $\mathrm{LG}$ at the tumor site. Numbers in the plot indicate percentages of the corresponding population. Data are representative of three independent experiments ( $n=5$ mice per group in each experiment). ns, not significant; ${ }^{*} P<0.05$, , ${ }^{* *} P<0.01$, ${ }^{* * *} P<$ 0.001 (Student's $t$-test). The symbol above each column is the $P$ value obtained when SP samples were compared to the corresponding samples from naive mice (control)

with TM progression. As tumor numbers increased, immune checkpoints including PD-1, TIM-3, TIGIT, and CTLA-4 increased (Additional file 3: Figure S3).

\section{Immunosuppressive function of tumor-infiltrating $T_{\text {reg }}$ in $\mathrm{CD}^{+} \mathrm{T}$ cell response is mediated by PD-1/PD-L1 interaction}

Among all IC-molecules examined, PD-1 was most highly upregulated in tumor-infiltrating $\mathrm{T}_{\text {reg }}$ cells. To determine the role of $\mathrm{PD}-1$ on tumor-infiltrating $\mathrm{T}_{\text {reg }}$ cells, in the regulation of the $\mathrm{CD}^{+} \mathrm{T}$ cell response, we compared the suppressive activity of $\mathrm{T}_{\text {reg }}$ expressing high- and low-levels of PD-1 (PD- ${ }^{\text {hi }} \mathrm{T}_{\text {reg }}$ cells from lung TM 3 weeks after TC-1 injection vs. PD- ${ }^{\text {lo }} \mathrm{T}_{\text {reg }}$ cells from the spleen of the same TM-bearing mice). $\mathrm{CD} 4{ }^{+} \mathrm{CD} 25^{+} \mathrm{T}_{\text {reg }}$ cells, isolated using a microbead-based Treg isolation kit $\left(\mathrm{CD} 4{ }^{+} \mathrm{CD} 25^{+}\right.$Regulatory $\mathrm{T}$ Cell Isolation kit), was confirmed to be $\sim 90 \%$ purified Foxp3 ${ }^{+}$ $\mathrm{T}_{\text {reg }}$ cells (Additional file 4: Figure $\mathrm{S} 4$ ). Each population was co-cultured with naïve $\mathrm{CD}^{+}$cells with or without stimulation by $\alpha \mathrm{CD} 3 / \mathrm{CD} 28$. $\mathrm{CD}^{+} \mathrm{T}$ cells proliferated at a high rate in the absence of $\mathrm{T}_{\text {reg }}$ cells and were more potently inhibited by PD- ${ }^{\text {hi }}$ tumor-infiltrating $\mathrm{T}_{\text {reg }}$ cells than by PD-1 ${ }^{\mathrm{lo}}$ spleen $\mathrm{T}_{\text {reg }}$ cells (Fig. 6a). Similarly, interferon (IFN) $-\gamma$ production was also more strongly suppressed by PD-1 ${ }^{\text {hi }}$ tumor-infiltrating $\mathrm{T}_{\text {reg }}$ than by PD-1 ${ }^{\text {lo }}$ spleen $\mathrm{T}_{\text {reg }}$ cells.

To investigate the role of PD-1 upregulation, induced by tumor-infiltrating $\mathrm{T}_{\text {reg }}$ cells, we examined whether the interaction between PD-1 on tumor-infiltrating $\mathrm{T}_{\text {reg }}$ cells and PD-L1 on $\mathrm{CD}^{+} \mathrm{T}$ cells is required for immunosuppression in patients with cancer. PD-1 on tumor-infiltrating $\mathrm{T}_{\text {reg }}$ cells was blocked by incubation with an anti-PD-1 antibody. Unbound antibody was subsequently removed and the cells were co-cultured with $\mathrm{CD}^{+} \mathrm{T}$ cells. We prepared $\mathrm{T}_{\text {reg }}$ cells, expressing an intermediate level of PD-1 that were isolated from lung TM in 2- rather than in 3-weeks after injection because $\mathrm{T}_{\text {reg }}$ cells, highly expressing PD-1, isolated at later timepoints, also co-expressed other IC-molecules (Fig. 5), making it difficult to differentiate the role of PD-1 in the suppressive function of $\mathrm{T}_{\text {reg }}$ cells from that of others.

Additionally, to clarify whether the potent suppressive function of PD- $1^{\text {hi }}$ tumor-infiltrating $\mathrm{T}_{\text {reg }}$ cells is mediated via cell-to-cell contact between $\mathrm{T}_{\text {reg }}$ and $\mathrm{CD} 8^{+}$cells or soluble factors produced from $\mathrm{T}_{\text {reg }}$ cells, we conducted the experiments with transwell membrane system to block cell migration (Fig. 6b). Transwell membranes were inserted into 24-well plate. CTV labeled $\mathrm{CD} 8^{+} \mathrm{T}$ cells and $\mathrm{CD} 4{ }^{+} \mathrm{CD} 25^{+} \mathrm{T}_{\text {reg }}$ were placed into lower and upper wells, respectively, and $\alpha \mathrm{CD} 3 / \mathrm{CD} 28$ was added into both wells for stimulation. Suppression of $\mathrm{T}$ cell proliferation was not observed in the presence of the Transwell membrane. This data demonstrated that the suppression of $\mathrm{CD}^{+} \mathrm{T}$ cell proliferation by $\mathrm{T}_{\text {reg }}$ requires cell to cell contact between each cell population (Fig. 6b). Next, we performed the in vivo experiment with TIL $\mathrm{T}_{\text {reg }}$ and spleen $\mathrm{T}_{\text {reg }}$ cellsalong with Ly5.1 ${ }^{+} \mathrm{CD} 8^{+} \mathrm{T}$ cells. In line with in vitro data, when TIL $\mathrm{T}_{\text {reg }}$ cells was injected, $\mathrm{CD}^{+} \mathrm{T}$ cell proliferation was significantly 


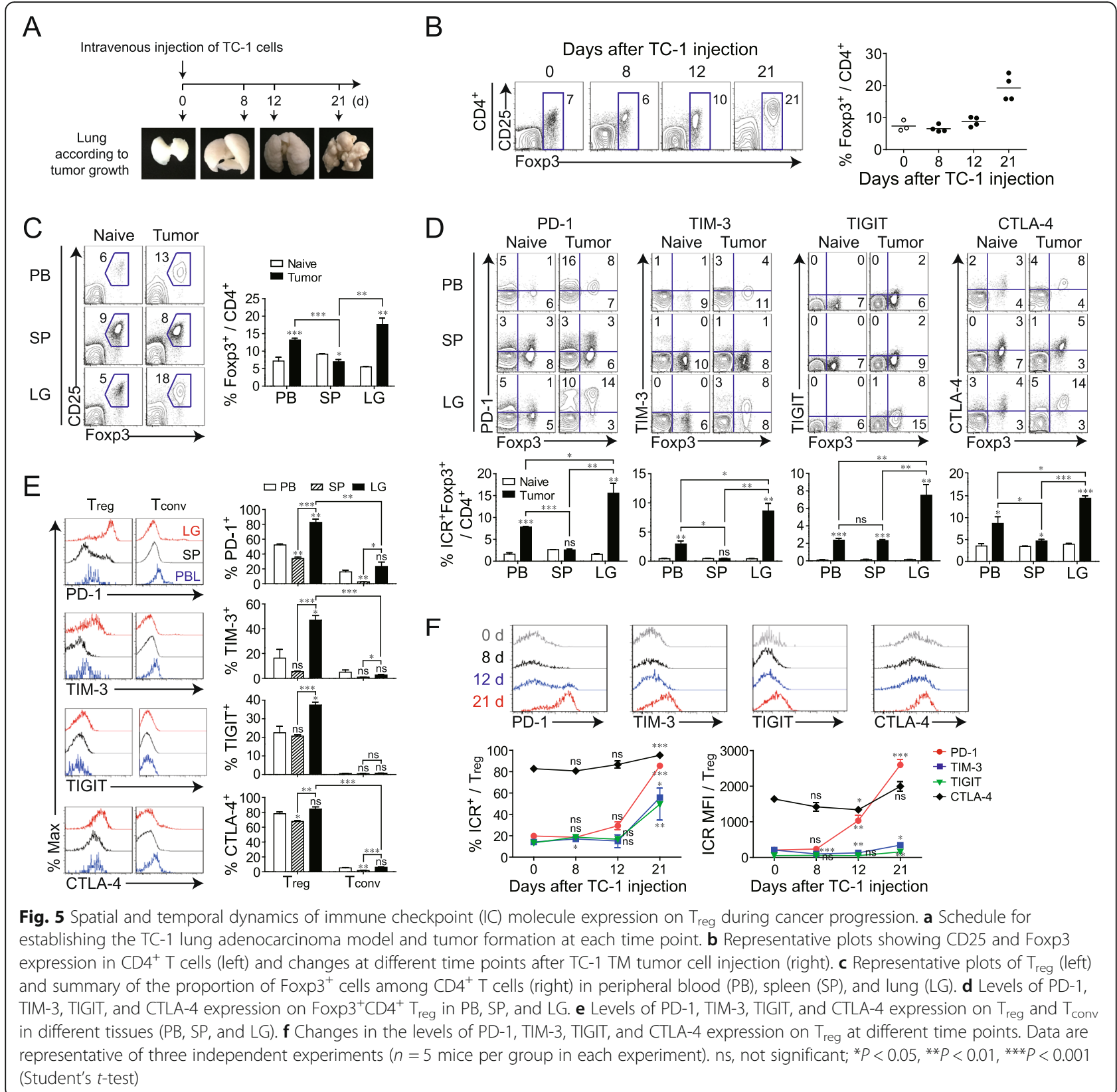

inhibited compared with spleen $\mathrm{T}_{\text {reg }}$ and no $\mathrm{T}_{\text {reg }}$ cells (Fig. 6c).

As shown in Fig. $6 \mathrm{~d}$, tumor-infiltrating $\mathrm{T}_{\text {reg }}$ cells that had been blocked with anti-PD-1 antibody, were significantly impaired in their ability to suppress the proliferation of $\mathrm{CD}^{+} \mathrm{T}$ cells and IFN- $\gamma$ production as compared to isotype antibody-treated tumorinfiltrating $\mathrm{T}_{\text {reg }}$ cells. Given that both mouse and human $\mathrm{CD}^{+} \mathrm{T}$ cells can upregulate low affinity $\mathrm{Fc}$ receptors following activation [24, 25], we tested whether $\mathrm{CD}^{+} \mathrm{T}$ cells upregulate $\mathrm{Fc}$ receptors in our system. We obtained splenocytes of TC-1 tumor bearing mice. We stained splenocytes with CD8, CD44,
CD16/32 (FcyRIII/II), and CellTrace Violet and compared the expression of Fc receptor between with and without stimulation. Significant differences of CD16/ 32 were not observed between groups with and without stimulation (Additional file 5: Figure S5A). To validate the CD16/32 antibody, we analyzed the expression of CD16/32 on NK cells and macrophages. This antibody can specifically detect CD16/32 on these cells, so we excluded the possibility that no detection of $\mathrm{CD} 16 / 32$ on $\mathrm{CD}^{+} \mathrm{T}$ cells after stimulation could be a problem of CD16/32 antibody (Additional file 5: Figure S5B). Taken together, our data demonstrated that the effect of anti-PD-1 is direct effect by 


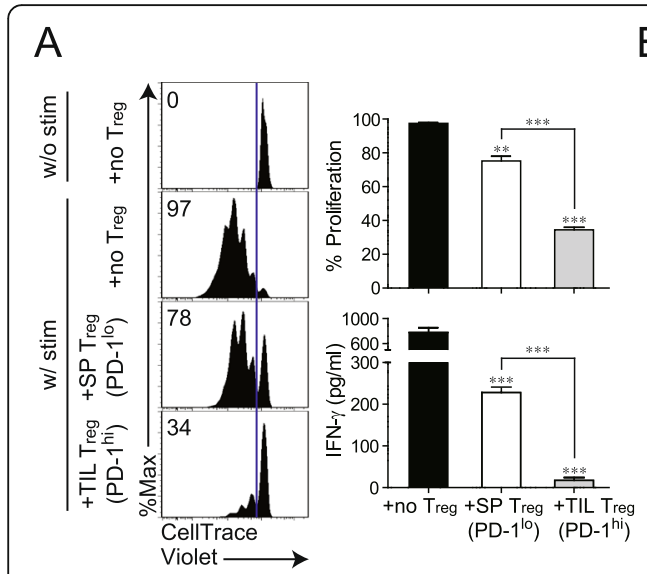

D

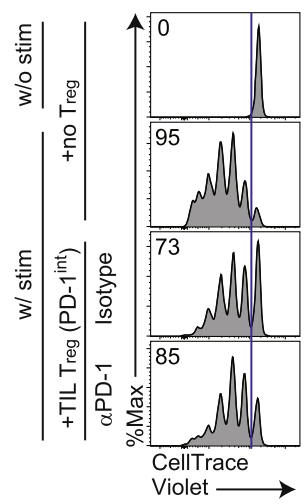

B

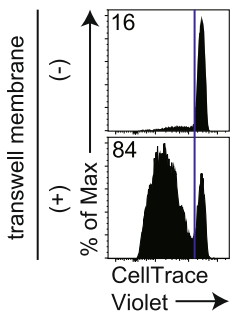

C

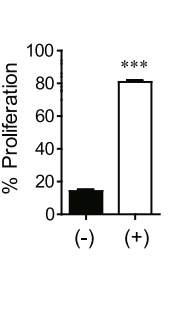

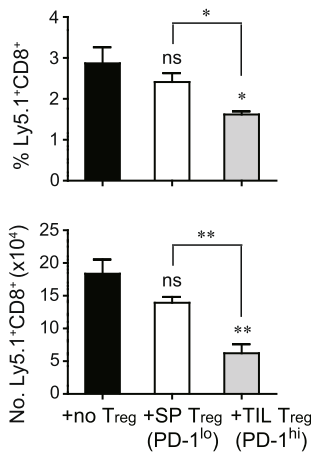

E
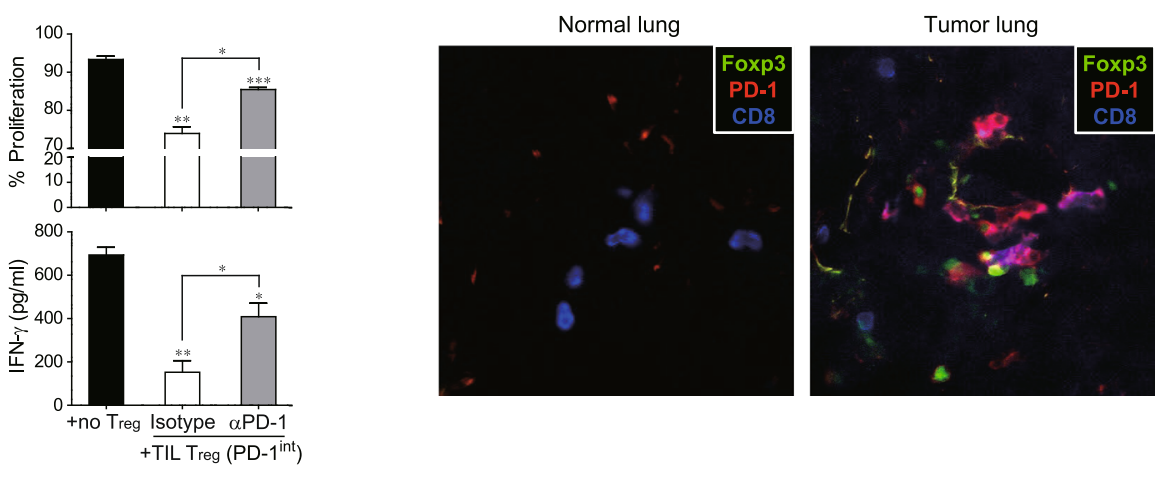

Fig. 6 Enhanced suppressive function of PD-1-expressing tumor-infiltrating $T_{\text {reg. }}$ a Enhanced suppression of CD8 ${ }^{+} T_{\text {cells }}$ by PD-1-expressing tumor-infiltrating $T_{\text {reg. }}$. At 3 weeks after intravenous injection of TC-1 cells, $T_{\text {reg }}$ were isolated from the spleen (SP) and lung of mice with TC-1 cellinduced tumors. SP $T_{\text {reg }}$ and tumor-infiltrating $T_{\text {reg }}$ expressed low and high levels of PD-1, respectively. CellTrace Violet (CTV)-labeled CD8 ${ }^{+} \mathrm{T}$ cells were stimulated in vitro with CD3/CD28 Dynabeads for $72 \mathrm{~h}$ in the absence or presence of each $\mathrm{T}_{\text {reg }}$ population. CTV dilution in proliferating $\mathrm{CD}^{+} \mathrm{T}$ cells is indicated in each histogram. Histograms represent the percentages of proliferating (upper) and IFN- $\gamma$-producing (lower) cells. $\mathbf{b}$

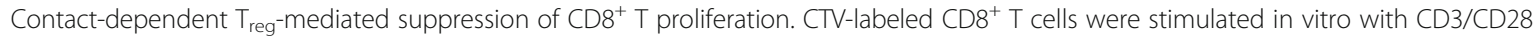
Dynabeads and cocultured with tumor-infiltrating $\mathrm{T}_{\text {reg }}$ for $72 \mathrm{~h}$ in the absence or presence of a transwell membrane. c Homeostatic proliferation of donor Ly $5.1^{+} \mathrm{CD}^{+} \mathrm{T}$ cells in the spleen isolated from Rag2 $2^{-/-}$mice at $7 \mathrm{~d}$ after adoptive cell transfer. Representative plot (left) and absolute number (right) of donor Ly5.1 ${ }^{+} \mathrm{CD}^{+} \mathrm{T}$ cells in the spleen. $\mathbf{d}$ PD-1-mediated suppressive activity of tumor-infiltrating $\mathrm{T}_{\text {reg }}$ isolated from the lungs of tumor-bearing mice 2 weeks after intravenous injection of TC-1 cells. At this time point, $\mathrm{T}_{\text {reg }}$ expressed intermediate levels of PD-1. CTV-labeled $\mathrm{CD}^{+} \mathrm{T}$ cells were stimulated as shown in (a). Before co-culture of CD8 ${ }^{+} \mathrm{T}$ cells with tumor-infiltrating $T_{\text {reg, }}$, the latter were pre-incubated with an anti-PD-1 antibody or its isotype as control. CTV dilution in proliferating CD8 ${ }^{+} \mathrm{T}$ cells is shown in the histograms, which represent the percentages of proliferating (upper) and IFN- $\gamma$-producing (lower) cells. (e) Representative immunofluorescence images of mouse lung tumor samples. Antibodies against Foxp3, CD8, and PD-1 were used to label and examine the interaction between $\mathrm{T}_{\text {reg }}$ and $\mathrm{CD} 8^{+} \mathrm{T}$ cells expressing PD1. Data are representative of two independent experiments. ${ }^{*} P<0.05$, ${ }^{* *} P<0.01,{ }^{* *} P<0.001$ (Student's t-test)

blocking of PD-1 pathway signaling rather than the effect of anti-PD-1 antibody mediated by ADCC.

A multi-color immunofluorescence analysis revealed that CD8, PD-1, and Foxp3 were co-localized in mouse tumor tissues (Fig. 6e), implying that $\mathrm{CD}^{+}$cells and Foxp $3^{+} \mathrm{T}_{\text {reg }}$ cells spatially interact in the TME.

\section{Discussion}

In this study, we examined the phenotype and function of $\mathrm{T}_{\text {reg }}$ cells as well as $\mathrm{CD}^{+}$and $\mathrm{CD}^{+} \mathrm{T}_{\text {conv }}$ cells that infiltrated into the TME, including the $\mathrm{ME}$ and TM from patients with cancer. We also investigated the mechanism by which $\mathrm{T}_{\text {reg }}$ cells induce immunosuppression using a mouse lung cancer model. Most tumor-infiltrating $\mathrm{T}_{\text {reg }}$ cells showed higher PD-1 expression than $\mathrm{T}_{\text {conv }}$ cells, implying that PD-1-expressing $\mathrm{T}_{\text {reg }}$ cells are a biological marker of the TME. Indeed, in $\mathrm{T}_{\text {reg }}$ cells derived from TMs of patients with NSCLC, PD-1 was the most clearly upregulated IC-molecule. As previously reported, these cells exhibited an enhanced immunosuppressive function that was correlated with the extent of PD-1 upregulation [12]. We speculate that PD-1-expressing tumor-infiltrating $\mathrm{T}_{\text {reg }}$ cells induce immunosuppression through the interaction of PD-1 and PD-L1, which may contribute to immune escape in TME. 
Clarifying the link between this phenotype and enhanced suppressive function of tumor-infiltrating $\mathrm{T}_{\text {reg }}$ cells can provide insight into their suppressive mechanism in patients with cancer.

The predominant function of PD- 1 in $\mathrm{T}_{\text {reg }}$ cells seems to be similar to that of CTLA-4; both proteins contribute to the maintenance of $\mathrm{T}_{\text {reg }}$ immunosuppressive function [15]. However, PD-1 expression on $\mathrm{T}_{\text {reg }}$ cells differed by cell location. For instance, PD-1 was expressed by $\mathrm{T}_{\text {reg }}$ cells in TMs but not in normal tissue or PBLs as depicted in Fig. 3. In contrast, $\mathrm{T}_{\text {reg }}$ cells had high basal CTLA-4 levels irrespective of the tissue of origin. This supports our assertion that PD- 1 on $\mathrm{T}_{\text {reg }}$ cells is a more useful marker for characterizing the TME. We also examined whether the upregulation of PD-1 on tumor-infiltrating $\mathrm{T}_{\text {reg }}$ cells can reinforce their basal immune-suppressive function. High PD-1 expression in $\mathrm{T}_{\text {reg }}$ cells was associated with the suppression of $\mathrm{CD} 8^{+} \mathrm{T}$ cells and PD-1 blockade abrogated the immunesuppressive function of $\mathrm{T}_{\text {reg }}$ cells, suggesting that an interaction between PD-1 on $\mathrm{T}_{\text {reg }}$ cells and PD-L1 expressed by another cell type-likely $\mathrm{CD}^{+} \mathrm{T}$ cells [26]-is necessary for immunosuppression. Thus, elevated PD-1 expression on $\mathrm{T}_{\text {reg }}$ cells is a potential marker for immune escape in patients with cancer. These findings were consistent with our previously reported data that PD-1 upregulation in $\mathrm{T}_{\text {reg }}$ cells and the interaction between PD-1 on $\mathrm{T}_{\text {reg }}$ cells and PD-L1 expressed by effector $\mathrm{T}$ cells enhanced $\mathrm{T}$ cell-mediated immune suppression during chronic viral infection [12]. Thus, an immunotherapy targeting $\mathrm{T}_{\text {reg }}$ and PD-1 could be highly effective in patients with cancer.

We also investigated tumor-infiltrating $\mathrm{T}_{\text {reg }}$ and $\mathrm{T}_{\text {conv }}$ cells obtained from ME of patients with stage IV cancer. Most of the earlier studies of TME $T_{\text {reg }}$ cells were performed in mice and focused on $\mathrm{T}_{\text {reg }}$ cells phenotype. Studies in patients with stage IV cancer have been hampered by the difficulty of obtaining sufficient TMs for analysis of $\mathrm{T}$ cell populations. To overcome this limitation, we developed an experimental model using ME from human patients with stage IV cancer as representative TME of stage IV cancer. This model will allow future examinations of various mechanistic aspects of human cancer through functional assays.

Several studies have reported IC expression on intratumoral $\mathrm{T}_{\mathrm{reg}}$ cells and suggested potential roles of these ICs in the regulation of the immune response in mice [6, $15,27]$. We also showed here that ICs other than PD-1 were upregulated in $\mathrm{T}_{\text {reg }}$ cells. Studies on the relative contributions of these IC-molecules to immunosuppression in the TME may lead to the development more effective immunotherapies.

Regarding other PD-1-expressing immune cells than $\mathrm{CD}^{+} \mathrm{T}$ cells and $\mathrm{T}_{\text {reg }}$ cells in TME and their role, Irving et al. reported that tumor-associated macrophages (TAMs) expressed PD-1 and PD-1-expressing TAMs increased over time in mouse model and progressive disease in human cancers [28]. PD-1 expressed on TAMs reduced their phagocytic potency against tumor cells and blockade of PD-1 pathway restored the macrophage phagocytosis, resulting in enhancing anti-tumor activity of TAMs. This data suggests that PD-1 expressed by TAMs is one of the mechanism for immune evasion. PD-1 expression was also described on NK cells in many different types of human and mouse cancers, where the PD-1 expressed by NK cells negatively regulated NK cell function even though its molecular mechanisms are not clearly demonstrated to date [29-34]. In addition, PD-1 has been reported to be expressed on innate lymphoid cells (ILCs), prevalently ILCs type 3 (ILC3s), as well as NK cells in pleural effusion of primary and metastatic tumors, albeit the role of PD-1 on ILC3s was not addressed [35].

Based on these reports, it is plausible that PD-1 expressed by different types of immune cells including CD8+ T cells, $\mathrm{T}_{\text {reg }}$ cells, NK cells, and ILCs in the TME probably contributes to immune evasion, leading to promotion of tumor cells. However, it has not been addressed yet which types of PD-1-expressing immune cells are most effectively involved in the PD-1-mediated immunosuppression. In addition, to compare the immunosuppressive activity of each immune cell subset, the level of PD-1 expression on each type of cells should be examined. In this regard, further study is needed to determine whether other PD-1-expressing immune cells than $T_{\text {reg }}$ cells in the TME compensate for a lack of $T_{\text {reg }}$ cells and which types of PD-1-expressing immune cells mostly impact on immune suppression in the TME.

$\mathrm{T}_{\text {reg }}$ cells expansion in the TME is widely recognized as an obstacle to successful immunotherapy in patients with cancer [5]. Previously, we demonstrated that $\mathrm{T}_{\text {reg }}$ cells depletion using an anti-CD25 antibody increased the abundance of functional antigen-specific $\mathrm{CD}^{+} \mathrm{T}$ cells during chronic viral infection [12]. Furthermore, treatment with a neutralizing antibody also caused the elimination of non- $\mathrm{T}_{\text {reg }}$ and rapid replenishment of $\mathrm{T}_{\text {reg }}$ cells [36]. Thus, functional inactivation of $\mathrm{T}_{\text {reg }}$ cells and rejuvenation of exhausted $\mathrm{T}$ cells by targeting overexpressed PD-1 combined with temporal depletion of $\mathrm{T}_{\text {reg }}$ cells expressing IC-molecules may be a promising strategy to limit cancer progression.

\section{Conclusions}

In conclusion, our study provides insights into $\mathrm{T}_{\text {reg }}$ cells function and their suppressive mechanism in patients with cancer. We showed that the suppressive function of tumor-infiltrating $\mathrm{T}_{\text {reg }}$ cells was enhanced by the increase in their relative proportion and by the upregulation of the expression of inhibitory receptors, such as PD-1, TIM-3, and CTLA-4. 


\section{Supplementary information}

Supplementary information accompanies this paper at https://doi.org/10. 1186/s40425-019-0785-8.

Additional file 1: Figure S1. PD-1 expression on $\mathrm{CD}^{+}, \mathrm{CD}^{+}$, or $\mathrm{T}_{\text {reg }}$ in malignant effusion according to the different types of cancer patients including lung cancer, gastric cancer, breast cancer, and others.

Additional file 2: Figure S2. Comparison of $\mathrm{T}_{\text {reg }}$ phenotype between ascites and pleural effusion. (A) Percentage of Foxp3 in total CD4 ${ }^{+} \mathrm{T}$ cells between ascites and pleural effusion (B) Percentage of PD- $1^{+} \mathrm{Foxp} 3^{+}$in total CD4 ${ }^{+} \mathrm{T}$ cells between ascites and pleural effusion (C) Percentage of PD- $1^{+}$in Foxp $3^{+}$CD4 $\mathrm{T}_{\text {reg }}$ between ascites and pleural effusion (Left), percentage of PD- $1^{+}$in Foxp3 ${ }^{-}$CD4 T cells between ascites and pleural effusion.

Additional file 3: Figure S3. Correlation of the immune checkpoint including PD-1, TIM-3, TIGIT and CTLA4 expressed on $T_{\text {reg }}$ as tumor nodule number increased. (A) PD-1, (B) TIM-3, (C) TIGIT, and (D) CTLA-4 expression on $T_{\text {reg }}$ according to the increased tumor nodules. The number of tumor nodules was measured at day 12, 16, and 21 post-injection ( $n=$ 4-7 mice per group). Data are representative of two independent experiments. ${ }^{*} P<0.05,{ }^{* *} P<0.01,{ }^{* * *} P<0.001$ (Student's $t$-test).

Additional file 4: Figure S4. Purification of tumor-infiltrating $T_{\text {reg }}$ using microbead-based Treg isolation kit. $T_{\text {reg }}$ were separately isolated from the spleen and from TM-bearing mice using a $\mathrm{CD} 4{ }^{+} \mathrm{CD} 25^{+}$Regulatory $\mathrm{T}$ Cell Isolation kit for suppressive function analysis. $T_{\text {reg, }}$ isolated using a microbead-based Treg isolation kit, demonstrated $\sim 90 \%$ purified Foxp3 ${ }^{+}$ $\mathrm{T}_{\text {reg }}$ compared with the $16 \%$ prior to isolation.

Additional file 5: Figure S5. Expression of CD16/32 on $C D 8^{+} T$ cells after in vitro TCR activation and NK cells and macrophages. (A) The expression of CD16/32 on purified $C D 8^{+} \mathrm{T}$ cells activated by $\mathrm{CD} 3 / 28$ Dynabeads for $3 \mathrm{~d}$. (B) The expression of CD16/32 on Dx $5^{+} \mathrm{NK} 1.1^{+} \mathrm{NK}$ cells and $\mathrm{CD} 11 \mathrm{~b}^{+} \mathrm{F} 4 / 80^{+}$macrophages isolated from the spleen of naive mouse.

Additional file 6: Table S1. Baseline characteristics of patients and specimens.

\section{Acknowledgements}

Not applicable.

\section{Declarations}

This manuscript has not been published or presented elsewhere in part or in entirety and is not under consideration by another journal. All study participants provided informed consent, and the study design was approved by the appropriate ethics review board. We have read and understood your journal's policies, and we believe that neither the manuscript nor the study violates any of these. There are no conflicts of interest to declare. The author contributions are described below.

\section{Authors' contributions}

Conception and design: HRK, SYP, SYR, S-JH. Financial support: HRK, S-JH. Administrative support: HRK, SYP, SYR, S-JH. Provision of study materials or patients: HRK, HJP, JS, JGL, KYC, NHC, HSS, SP, GMK, HIY, HGK, YWJ, BCC, SYP, SYR, S-JH. Collection and assembly of data: HRK, HJP, JS, JGL, KYC, GMK, HIY, HGK, YWJ, BCC, SYP, SYR, S-JH. Data analysis and interpretation: HRK, HJP, SYP, SYR, S-JH. Manuscript writing: All authors. Final approval of manuscript: All authors.

\section{Funding}

This work was supported by grants from the National Research Foundation of the Republic of Korea (2018R1A2A1A05076997, 2017R1A5A1014560, 2018M3A9H3024850, and 2019M3A9B6065221 to S-J.H.; 2017M3A9E9072669, 2017M3A9E8029717, 2017R1D1A1B03029874, and 2019M3A9B6065231 to H.R.K).

\section{Availability of data and materials}

All data generated or analysed during this study are included in this published article and its supplementary information files.

\section{Ethics approval and consent to participate}

The study was approved by the Institutional Review Board of Severance Hospital. All animal protocols were approved by the Institutional Animal Care and Use Committee of the Yonsei University Laboratory Animal Research Center (2013-0115)

\section{Consent for publication}

All authors agreed with publication.

\section{Competing interests}

The authors declare that they have no competing interest that are relevant to this study.

\section{Author details}

${ }^{1}$ Yonsei Cancer Center, Division of Medical Oncology, Yonsei University College of Medicine, 50 Yonsei-ro, Seodaemun-Gu, Seoul 120-752, South Korea. ${ }^{2}$ Department of Biochemistry, College of Life Science \& Biotechnology, Yonsei University, Seoul, South Korea. ${ }^{3}$ Department of Thoracic and Cardiovascular Surgery, Yonsei University College of Medicine, 50 Yonsei-ro, Seodaemun-Gu, Seoul 120-752, South Korea. ${ }^{4}$ Department of Pathology, Yonsei University College of Medicine, Seoul, South Korea. ${ }^{5}$ Department of Radiation Oncology, Yonsei University College of Medicine, Seoul, South Korea. ${ }^{6}$ Department of Pharmacy, Korea University, Sejong, South Korea.

Received: 13 December 2018 Accepted: 22 October 2019

Published online: 04 December 2019

\section{References}

1. Gettinger SN, Horn L, Gandhi L, Spigel DR, Antonia SJ, Rizvi NA, et al. Overall survival and long-term safety of Nivolumab (anti-programmed death 1 antibody, BMS-936558, ONO-4538) in patients with previously treated advanced non-small-cell lung Cancer. J Clin Oncol. 2015;33(18):2004. https:// doi.org/10.1200/jco.2014.58.3708.

2. Garon EB, Rizvi NA, Hui R, Leighl N, Balmanoukian AS, Eder JP, et al. Pembrolizumab for the treatment of non-small-cell lung Cancer. N Engl J Med. 2015. https://doi.org/10.1056/NEJMoa1501824.

3. Ribas A. Tumor immunotherapy directed at PD-1. N Engl J Med. 2012; 366(26):2517-9.

4. Sakuishi K, Apetoh L, Sullivan JM, Blazar BR, Kuchroo VK, Anderson AC. Targeting Tim-3 and PD-1 pathways to reverse T cell exhaustion and restore anti-tumor immunity. J Exp Med. 2010;207(10):2187-94.

5. Nishikawa $H$, Sakaguchi S. Regulatory T cells in tumor immunity. Int J Cancer. 2010;127(4):759-67.

6. Kurtulus S, Sakuishi K, Ngiow SF, Joller N, Tan DJ, Teng MW, et al. TIGIT predominantly regulates the immune response via regulatory $T$ cells. J Clin Invest. 2015:125(11):4053-62.

7. Scurr MJ, Pembroke T, Bloom A, Roberts DJ, Thomson A, Smart K, et al. Low-dose cyclophosphamide induces anti-tumor T-cell responses which associate with survival in metastatic colorectal cancer. Clin Cancer Res. 2017. https://doi.org/10.1158/1078-0432.ccr-17-0895.

8. Sugiyama D, Nishikawa H, Maeda Y, Nishioka M, Tanemura A, Katayama I, et al. Anti-CCR4 mAb selectively depletes effector-type FoxP3+CD4+ regulatory $T$ cells, evoking antitumor immune responses in humans. Proc Natl Acad Sci U S A. 2013;110(44):17945-50.

9. Park HJ, Kusnadi A, Lee EJ, Kim WW, Cho BC, Lee IJ, et al. Tumor-infiltrating regulatory $T$ cells delineated by upregulation of PD-1 and inhibitory receptors. Cell Immunol. 2012;278(1-2):76-83.

10. Kang MJ, Kim KM, Bae JS, Park HS, Lee H, Chung MJ, et al. Tumor-infiltrating PD1-positive lymphocytes and FoxP3-positive regulatory $T$ cells predict distant metastatic relapse and survival of clear cell renal cell carcinoma. Transl Oncol. 2013;6(3):282-9.

11. Penaloza-MacMaster P, Kamphorst AO, Wieland A, Araki K, lyer SS, West EE, et al. Interplay between regulatory T cells and PD-1 in modulating T cell exhaustion and viral control during chronic LCMV infection. J Exp Med. 2014;211(9):1905-18

12. Park HJ, Park JS, Jeong YH, Son J, Ban YH, Lee BH, et al. PD-1 Upregulated on regulatory $T$ cells during chronic virus infection enhances the suppression of CD8+ T cell immune response via the interaction with PD-L1 expressed on CD8+ T cells. J Immunol. 2015;194(12):5801-11. 
13. Sakuishi K, Ngiow SF, Sullivan JM, Teng MW, Kuchroo VK, Smyth MJ, et al. TIM3FOXP3 regulatory T cells are tissue-specific promoters of T-cell dysfunction in cancer. Oncoimmunology. 2013;2(4):e23849.

14. Gautron AS, Dominguez-Villar M, de Marcken M, Hafler DA. Enhanced suppressor function of TIM-3+ FoxP3+ regulatory T cells. Eur J Immunol. 2014;44(9):2703-11.

15. Wing $K$, Onishi $Y$, Prieto-Martin P, Yamaguchi T, Miyara M, Fehervari Z, et al. CTLA-4 control over Foxp3+ regulatory T cell function. Science. 2008; 322(5899):271-5.

16. Sojka DK, Hughson A, Fowell DJ. CTLA-4 is required by CD4+CD25+ Treg to control CD4+ T-cell lymphopenia-induced proliferation. Eur J Immunol. 2009;39(6):1544-51.

17. Francisco LM, Salinas VH, Brown KE, Vanguri VK, Freeman GJ, Kuchroo VK, et al. PD-L1 regulates the development, maintenance, and function of induced regulatory T cells. J Exp Med. 2009;206(13):3015-29.

18. Periasamy S, Dhiman R, Barnes PF, Paidipally P, Tvinnereim A, Bandaru A, et al. Programmed death 1 and cytokine inducible $\mathrm{SH}$ 2-containing protein dependent expansion of regulatory $T$ cells upon stimulation with mycobacterium tuberculosis. J Infect Dis. 2011;203(9):1256-63.

19. Wang L, Pino-Lagos K, de Vries VC, Guleria I, Sayegh MH, Noelle RJ. Programmed death 1 ligand signaling regulates the generation of adaptive Foxp3+CD4+ regulatory T cells. Proc Natl Acad Sci U S A. 2008;105(27): 9331-6.

20. Franceschini D, Paroli M, Francavilla V, Videtta M, Morrone S, Labbadia G et al. PD-L1 negatively regulates CD4+CD25+Foxp3+ Tregs by limiting STAT-5 phosphorylation in patients chronically infected with HCV. J Clin Invest. 2009;119(3):551-64.

21. Radziewicz H, Dunham RM, Grakoui A. PD-1 tempers Tregs in chronic HCV infection. J Clin Invest. 2009;119(3):450-3.

22. Shen $T$, Zheng J, Liang $H, X u C$, Chen $X$, Zhang $T$, et al. Characteristics and PD-1 expression of peripheral CD4+CD127loCD25hiFoxP3+ Treg cells in chronic HCV infected-patients. Virol J. 2011:8:279.

23. Lowther DE, Goods BA, Lucca LE, Lerner BA, Raddassi K, van Dijk D, et al. PD-1 marks dysfunctional regulatory $T$ cells in malignant gliomas. JCl Insight. 2016;1(5):1.

24. Dhanji S, Tse K, Teh HS. The low affinity fc receptor for lgG functions as an effective cytolytic receptor for self-specific CD8 T cells. J Immunol. 2005; 174(3):1253-8

25. Kudo K, Imai C, Lorenzini P, Kamiya T, Kono K, Davidoff AM, et al. T lymphocytes expressing a CD16 signaling receptor exert antibodydependent cancer cell killing. Cancer Res. 2014;74(1):93-103.

26. Zelenay S, Lopes-Carvalho T, Caramalho I, Moraes-Fontes MF, Rebelo M, Demengeot J. Foxp3+ CD25- CD4 T cells constitute a reservoir of committed regulatory cells that regain CD25 expression upon homeostatic expansion. Proc Natl Acad Sci U S A. 2005;102(11):4091-6.

27. Kolar P, Knieke K, Hegel JK, Quandt D, Burmester GR, Hoff H, et al. CTLA-4 (CD152) controls homeostasis and suppressive capacity of regulatory $T$ cells in mice. Arthritis Rheum. 2009;60(1):123-32.

28. Gordon SR, Maute RL, Dulken BW, Hutter G, George BM, McCracken MN et al. PD-1 expression by tumour-associated macrophages inhibits phagocytosis and tumour immunity. Nature. 2017:545(7655):495-9.

29. Beldi-Ferchiou A, Lambert M, Dogniaux S, Vely F, Vivier E, Olive D, et al. PD1 mediates functional exhaustion of activated NK cells in patients with Kaposi sarcoma. Oncotarget. 2016;7(45):72961-77.

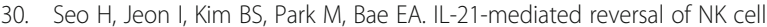
exhaustion facilitates anti-tumour immunity in MHC class I-deficient tumours. Nat Commun. 2017;8:15776.

31. Seo H, Kim BS, Bae EA, Min BS, Han YD, Shin SJ, et al. IL21 therapy combined with PD-1 and Tim-3 blockade provides enhanced NK cell antitumor activity against MHC class I-deficient tumors. Cancer Immunol Res. 2018;6(6):685-95.

32. Iraolagoitia XL, Spallanzani RG. NK Cells Restrain Spontaneous Antitumor CD8+ T Cell Priming through PD-1/PD-L1 Interactions with Dendritic Cells. J Immun. 2016;197(3):953-61.

33. Liu Y, Cheng Y, Xu Y, Wang Z, Du X, Li C, et al. Increased expression of programmed cell death protein 1 on NK cells inhibits NK-cell-mediated antitumor function and indicates poor prognosis in digestive cancers. Oncogene. 2017;36(44):6143-53.

34. Vari F, Arpon D, Keane C, Hertzberg MS, Talaulikar D, Jain S, et al. Immune evasion via PD-1/PD-L1 on NK cells and monocyte/macrophages is more prominent in Hodgkin lymphoma than DLBCL. Blood. 2018;131(16):1809-19.
35. Tumino N, Martini S, Munari E, Scordamaglia F, Besi F, Mariotti FR, et al. Presence of innate lymphoid cells in pleural effusions of primary and metastatic tumors: Functional analysis and expression of PD-1 receptor. Int $J$ Cancer. 2019;145(6):1660-8.

36. Setiady YY, Coccia JA, Park PU. In vivo depletion of CD4+FOXP3+ Treg cells by the PC61 anti-CD25 monoclonal antibody is mediated by FcgammaRIII+ phagocytes. Eur J Immunol. 2010;40(3):780-6.

\section{Publisher's Note}

Springer Nature remains neutral with regard to jurisdictional claims in published maps and institutional affiliations.
Ready to submit your research? Choose BMC and benefit from:

- fast, convenient online submission

- thorough peer review by experienced researchers in your field

- rapid publication on acceptance

- support for research data, including large and complex data types

- gold Open Access which fosters wider collaboration and increased citations

- maximum visibility for your research: over $100 \mathrm{M}$ website views per year

At BMC, research is always in progress.

Learn more biomedcentral.com/submissions 